\title{
Adaptation of Trifolium repens $\times$ T. uniflorum hybrid clovers to drought stress
}

\author{
KEITH WIDDUP ${ }^{1}$, SHIRLEY NICHOLS ${ }^{1,2}$, WARREN WILLIAMS ${ }^{3,4}$, ISABELLE VERRY $^{3}$ and BEN HARVEY ${ }^{1}$ \\ ${ }^{1}$ AgResearch, Lincoln Research Centre, Private Bag 4749, Christchurch \\ ${ }^{2}$ AgResearch, Ruakura Research Centre, Private Bag 3123, Hamilton \\ ${ }^{3}$ AgResearch Grasslands, Private Bag 11008, Palmerston North \\ ${ }^{4}$ College of Sciences, Massey University, Palmerston North
}

\begin{abstract}
White clover (Trifolium repens L.) is valued for its contribution to pasture quality and utilisation by animals, compatibility with grass, and fixation of nitrogen. However, it is limited by poor adaptation to drought. Hybridisation with Trifolium uniflorum L. may have potential to improve the drought resistance of white clover. An experiment in a rain shelter facility with contrasting moisture treatments, and a field evaluation under dryland conditions, were used to compare the agronomic potential of these interspecific hybrids (ISH) with white clover in moisture limited conditions. In the rain shelter experiment, there were smaller effects of water stress on shoot dry weight (DW), leaf area, internode length and senescence of first backcross generation hybrids compared with white clover and second backcross generation hybrids. Differences in photosynthetic responses were possibly influenced by the effect of root DW allocation on water uptake. In the field evaluation, growth scores of a wider range of hybrid families during summer moisture stress concurred with the results under water stress in the rain shelter. Growth of some ISH families outperformed the best white clover cultivars, particularly in the third and most stressful summer and this result was a key performance indicator of the value of the hybrids for drought prone areas. These findings using early, unselected, hybrid populations indicate the potential for further selection of elite, adapted cultivars from ISH breeding strategies.
\end{abstract}

Keywords: Interspecific clover hybrid, drought resistance, rain shelter, field evaluation

\section{Introduction}

In New Zealand, soil moisture is a limiting factor in the use and productivity of white clover (Trifolium repens L.). Episodic drought events can severely decrease white clover production (Knowles et al. 2003) and annual clovers and lucerne are currently the best adapted legume species for dryland pastures. Extensive droughts in higher rainfall regions during 2012/13 and 2013/14 also highlight the increasing importance of improving the drought resistance of white clover to guard against the present and future impacts of climate change on high production pastures.

Interspecific hybridisation of white clover with close relatives has potential to extend its gene-pool beyond current limitations. Through effective breeding strategies, this may expand white clover's adaptation to summer drought-prone pastoral regions. Eight species combinations were described at the 2010 NZGA conference (Williams et al. 2010). The $T$. repens $\times T$. ambiguum hybrid was the earliest hybrid developed, to take advantage of $T$. ambiguum's deep root and rhizome system, which is associated with drought resistance and persistence. Even though field studies indicated some potential for these hybrids (Widdup et al. 2003), further genetic development has been hindered due to poor chromosome pairing and introgression in the hexaploid hybrid (Williams et al. 2011). New research uses T. occidentale as a genetic bridge between $T$. repens and T. ambiguum leading to a more genetically stable tetraploid hybrid. In contrast, the $T$. repens $\times T$. uniflorum hybrids are relatively easy to work with, as they are highly fertile and backcross readily to white clover. This paper focuses on the performance of this hybrid combination under moisture limited conditions, investigating the potential for improved drought resistance compared with white clover and identifying traits that may be associated with this.

Trifolium uniflorum is a close, wild relative of white clover (Ellison et al. 2006) that naturally occurs in the Mediterranean region. It may possess adaptations that confer tolerance of low soil moisture, including relatively thick, deep roots; a woody taproot; and small, relatively thick, waxy leaves. Previous studies have indicated root traits in T. repens $\times$ T. uniflorum hybrids that may contribute to drought resistance, including a high ratio of thick roots (Hussain et al. 2012) which may penetrate to deeper soil layers. Trifolium uniflorum may also have evolved physiological adaptations to soil moisture stress. This paper focuses predominantly on the growth and morphological response of the T. repens $\times$ T. uniflorum hybrid. 


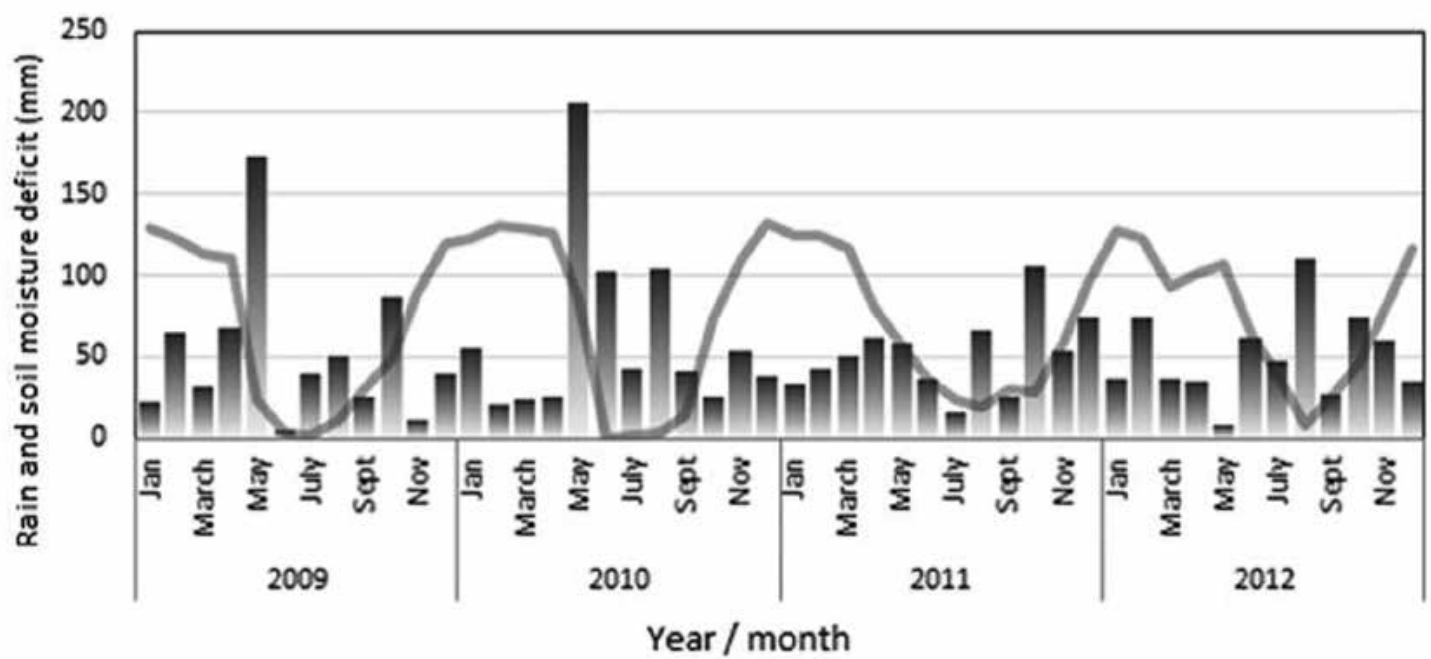

Figure 1 Monthly rainfall (bars) and soil moisture deficit (SMD, line) at Ashley Dene during the 2009-2012 period. SMD is derived from NIWA's estimate of daily soil moisture.

\section{Materials and Methods}

To determine the effect of water deficit on $T$. repens $\times T$. uniflorum interspecific hybrids, we conducted an experiment under controlled field conditions in a rain shelter. This enabled identification of traits that may contribute to potential drought resistance. In a second experiment, a range of hybrid families was screened under dryland Canterbury conditions in a 3 year field trial, incorporating both the taprooted and clonal phases of growth, to determine the plant's adaptation potential in soils with a low water holding capacity.

\section{Rain Shelter Experiment}

The rain shelter was located near Lincoln, Canterbury, New Zealand, on a Templeton silt loam. Plants were established in a glasshouse from cuttings, and transplanted to the experimental site on 1 October 2009. There were 16 clover entries, comprising five white clover cultivars with a range of leaf size classes, seven first backcross $\left(\mathrm{BC}_{1}\right)$, and four second backcross $\left(\mathrm{BC}_{2}\right)$ T. repens $\times T$. uniflorum hybrid families. The white clover cultivars and the backcross parents used in the $\mathrm{BC}_{1}$ entries were all common to both the cultivar and $\mathrm{BC}_{1}$ groups.

The experimental design was a split-plot arrangement, with six replicates of two watering treatments. Clover entries were assigned at random within each plot, in a four $\times$ four layout. Watering treatments were imposed from 8 December 2009 to 28 March 2010. Plots in the Watered treatment were irrigated weekly to replace potential evapotranspiration plus $10-20 \mathrm{~mm}$, and plots in the Stressed treatment received no irrigation. Neither treatment received additional water from rainfall, as the rain shelter pulled over the site during rain events.
Prior to harvest, all plants were scored for senescence from 1 (low senescence) to 10 (completely dead), growth pattern (tight and compact to open and spreading), and growth habit (prostrate to erect). Stolon density (low to high) was scored in the Stressed treatment only. Stolon morphological measurements were made on two stolons from each plant. A subset of entries (Kopu II $\mathrm{BC}_{1}$, Kopu II $\mathrm{BC}_{2}$ and 'Kopu II') was sampled for net photosynthesis, and for root dry weight (DW) in $10 \mathrm{~cm}$ diameter $\times 10 \mathrm{~cm}$ deep soil cores taken over the centre of each plant. At final harvest, all above ground plant parts were removed, dried at $80^{\circ} \mathrm{C}$ for 48 hours, and weighed. Stolon morphology data were analysed using linear mixed models in SAS version 9.1, and all other data were analysed via ANOVA in GenStat version 11.

\section{Field Experiment}

The experiment was conducted from October 2009 to March 2012 at a dryland site on Lincoln University's Ashley Dene Research Farm near Lincoln. The experiment involved plants that were transplanted into a Balmoral stony silt loam with a depth to stones $<20$ $\mathrm{cm}$ and $50 \mathrm{~mm}$ soil water holding capacity. The total monthly rainfall and levels of soil moisture deficit for the 2009-12 years are presented in Figure 1. Soil fertility was adequate for clover growth at the site (Olsen $\mathrm{P}=$ $30 \mu \mathrm{g} / \mathrm{ml}, \mathrm{S}=12 \mathrm{ppm}$ ) and no additional fertiliser was applied at the beginning of the experiment.

The hybrid plant material screened consisted of $38 \mathrm{BC}_{1}$ and $80 \mathrm{BC}_{2}$ lines together with white clover cultivars 'Kopu II', 'Tribute', 'Crusader' and 'Nomad' as controls. All backcrosses were to New Zealand bred white clover plants from cultivars including small, medium and large leaf size. Seedlings were established 
in $10 \mathrm{~cm}$ deep root-trainers containing a soil-peat mix in the glasshouse in July 2009.

The field site was sprayed with glyphosate and dicamba herbicides to remove all weed plants including legume seedlings six months prior to planting in early October 2009. The experimental design was a randomised complete block with entries replicated five times, where each plot consisted of ten plants in a two $\times$ five grid, with plants spaced $70 \mathrm{~cm}$ apart. The experiment was completely defoliated by grazing sheep in October, December, March and August each year after plants were scored. Growth of plants was assessed visually prior to each grazing on a scale of 1 (smallest) to 9 (largest). Plants were also scored for stolon density (low to high) and leaf size (small to large) in March 2011. During the third summer (February 2012), the number of plants with $50 \%$ green leaf or greater were counted in each plot. Growth data were analysed fitting a linear additive effects model and presented by box and whisker graphs using the package R. Analysis of morphological variables used ANOVA in GenStat version 16.

\section{Results}

\section{Rain Shelter Experiment}

Changes in volumetric soil moisture over time differed between treatments $(\mathrm{P} \leq 0.01)$. At the end of the experiment, soil moisture at $0.20 \mathrm{~m}$ averaged $10 \%$ in the Stressed treatment and $28 \%$ in the Watered treatment; at $0.95 \mathrm{~m}$ depth, soil moisture averaged $30 \%$ in both treatments.
Shoot DW in the Watered treatment was higher for white clover than for $\mathrm{BC}_{1}$ and $\mathrm{BC}_{2}$ (Table 1). However, DW of white clover did not differ from the $\mathrm{BC}_{1}$ generation in the Stressed treatment, due to a larger effect of water stress on the white clover plants. Similar relative differences and responses were observed for leaf area and internode length (Table 2). Larger decreases in shoot DW under water stress were correlated with larger leaf size $(\mathrm{P}=0.038, \mathrm{R}=0.214)$ in the Watered treatment, and also with larger decreases in leaf area under water stress $(\mathrm{P}=0.013, \mathrm{R}=0.263)$.

Larger decreases in shoot DW under stress were also correlated with larger increases in senescence ( $\mathrm{P}$ $=0.007, \mathrm{R}=-0.273)$. The effect of water stress was larger for $\mathrm{BC}_{2}$ and white clover than for $\mathrm{BC}_{1}(\mathrm{P}=$ $0.032)$. There was no difference in mean senescence score between treatments for $\mathrm{BC}_{1}$, resulting in lower senescence under water stress compared with $\mathrm{BC}_{2}$ and white clover (Table 1). Decreases in shoot DW were also correlated with higher senescence under water stress $(\mathrm{P}=0.008, \mathrm{R}=-0.271)$.

Net photosynthesis was maintained under water stress in Kopu II BC $\mathrm{BC}_{1}$, but decreased by over $40 \%$ in Kopu II BC ${ }_{2}$ and 'Kopu II' (Table 1). Increases in the root subsample $\mathrm{DW}$ under water stress were significant only for Kopu II $\mathrm{BC}_{1}$ (Table 1). The root subsample DW of Kopu II $\mathrm{BC}_{2}$ was smaller than Kopu II $\mathrm{BC}_{1}$ in the Stressed treatment (Table 1), a trend which was correlated with larger decreases in shoot DW ( $\mathrm{P}=$ $0.044, \mathrm{R}=0.480)$.

Table 1 Mean shoot dry weight (DW), senescence score, net photosynthesis and root subsample dry weight (DW) in the Watered (W) and Stressed (S) treatments. Net photosynthesis and root DW were measured in a subset of related entries. Means with the same letter within columns, or within rows for individual traits, are not significantly different.

\begin{tabular}{|c|c|c|c|c|c|c|c|c|}
\hline & \multicolumn{2}{|c|}{$\begin{array}{l}\text { Shoot } \\
\text { DW (g) }\end{array}$} & \multicolumn{2}{|c|}{$\begin{array}{c}\text { Senescence } \\
\text { 1=low, } 10=\text { high }\end{array}$} & \multicolumn{2}{|c|}{$\begin{array}{l}\text { Net photosynthesis } \\
\qquad\left(\mu \mathrm{mol} / \mathrm{m}^{2} / \mathrm{s}\right)\end{array}$} & \multicolumn{2}{|c|}{$\begin{array}{l}\text { Root subsample } \\
\text { DW (g) }\end{array}$} \\
\hline & W & $S$ & W & $S$ & W & $S$ & W & $S$ \\
\hline $\mathrm{BC}_{1}$ & $254 \mathrm{c}$ & $135 \mathrm{de}$ & $1.9 \mathrm{~b}$ & $2.3 \mathrm{~b}$ & $25.7 \mathrm{a}$ & $22.2 \mathrm{a}$ & $4.1 \mathrm{~b}$ & $6.4 \mathrm{a}$ \\
\hline $\mathrm{BC}_{2}$ & $321 \mathrm{~b}$ & $102 \mathrm{e}$ & $2.3 b$ & $3.4 \mathrm{a}$ & $23.2 \mathrm{a}$ & $12.0 \mathrm{~b}$ & $4.8 a b$ & $3.7 \mathrm{~b}$ \\
\hline White & $496 \mathrm{a}$ & $155 \mathrm{~d}$ & $1.9 \mathrm{~b}$ & $3.8 \mathrm{a}$ & $21.8 \mathrm{a}$ & $12.2 b$ & $3.9 \mathrm{~b}$ & $5.2 a b$ \\
\hline
\end{tabular}

Table 2 Mean leaf area, internode length and petiole length in the Watered (W) and Stressed (S) treatments, and the effect of water stress (Watered-Stressed) on these means. Means with the same letter, within columns, are not significantly different.

\begin{tabular}{|c|c|c|c|c|c|c|c|c|c|}
\hline & \multicolumn{3}{|c|}{ Leaf area $\left(\mathrm{mm}^{2}\right)$} & \multicolumn{3}{|c|}{ Internode length (mm) } & \multicolumn{3}{|c|}{ Petiole length (mm) } \\
\hline & W & $\mathrm{S}$ & W-S & W & $S$ & W-S & W & $S$ & W-S \\
\hline $\mathrm{BC}_{1}$ & $746 a$ & $260 a$ & $486 \mathrm{a}$ & $13.7 \mathrm{a}$ & $9.4 \mathrm{a}$ & $4.3 \mathrm{a}$ & $121.1 \mathrm{a}$ & $38.5 \mathrm{a}$ & $82.7 \mathrm{a}$ \\
\hline $\mathrm{BC}_{2}$ & $935 \mathrm{~b}$ & $254 \mathrm{a}$ & $681 \mathrm{~b}$ & $20.5 b$ & $11.2 a b$ & $9.3 b$ & $111.4 \mathrm{a}$ & $28.6 \mathrm{a}$ & $82.8 \mathrm{a}$ \\
\hline White & $1206 \mathrm{c}$ & $318 a$ & $888 \mathrm{~b}$ & $22.6 \mathrm{~b}$ & $13.9 \mathrm{~b}$ & $8.7 \mathrm{~b}$ & $135.8 b$ & $32.6 \mathrm{a}$ & $103.3 \mathrm{~b}$ \\
\hline
\end{tabular}




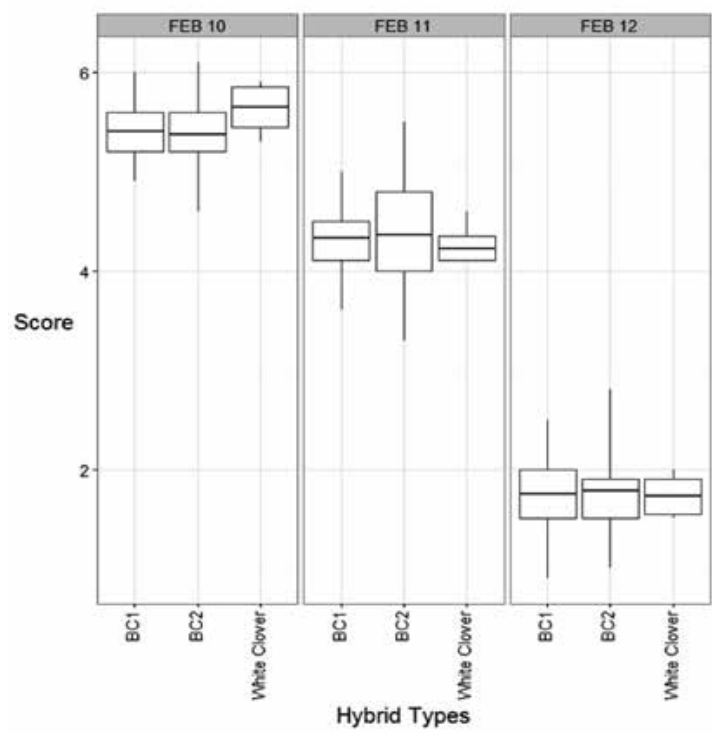

Figure 2 The mean summer growth and extent of variation for the $\mathrm{BC}_{1}$ and $\mathrm{BC}_{2}$ hybrid types compared to white clover (four cultivars) in February 2010, 2011 and 2012. A box presents the lower to upper quartile of entries with the mean $(-)$, and the vertical lines extend to the lowest and highest lines for each clover type.

In general, $\mathrm{BC}_{1}$ hybrids were more prostrate than white clover $(\mathrm{P}<0.05)$, and under water stress had a more compact and tight growth pattern $(\mathrm{P}<0.001)$, and a higher stolon density $(\mathrm{P}<0.001)$, whereas white clover had a more spreading and open growth pattern.

\section{Field Experiment}

The shallow, stony soil together with consistently low monthly rainfall resulted in a soil moisture deficit greater than $75 \mathrm{~mm}$ over the November to April period in all three years of the trial (Figure 1). This level is sufficient to stress plants and limit growth.

The mean summer growth and variation of the $\mathrm{BC}_{1}$ and $\mathrm{BC}_{2}$ hybrid types compared with white clover in February 2010, 2011 and 2012 are shown in Figure 2.

Table 3 Mean stolon density and leaf size scored in March 2011 and percentage of green plants in January 2012 for the $\mathrm{BC}_{1}$ and $\mathrm{BC}_{2}$ hybrid types and white clover at Ashley Dene, Canterbury. Means with the same letter, within columns, are not significantly different.

\begin{tabular}{lccc}
\hline & $\begin{array}{c}\text { Stolon Density } \\
\text { 1=low, 5=High }\end{array}$ & $\begin{array}{c}\text { Leaf size } \\
\text { 1=small, 5=large }\end{array}$ & $\begin{array}{c}\text { \% Green } \\
\text { Plants }\end{array}$ \\
\hline $\mathrm{BC}_{1}$ & $2.8 \mathrm{a}$ & $2.6 \mathrm{c}$ & $13 \mathrm{a}$ \\
$\mathrm{BC}_{2}$ & $2.8 \mathrm{a}$ & $2.8 \mathrm{~b}$ & $13 \mathrm{a}$ \\
White clover & $2.5 \mathrm{~b}$ & $3.1 \mathrm{a}$ & $14 \mathrm{a}$ \\
\hline
\end{tabular}

A decline in summer growth of all clover types from the first to second year $(\mathrm{P}<0.001)$ and then a major collapse in growth between the second and third years $(\mathrm{P}<0.001)$ was observed. However, within each year there was no significant difference in average growth among the hybrid types $\left(\mathrm{BC}_{1}\right.$ and $\left.\mathrm{BC}_{2}\right)$ and white clover. Although the mean summer growth was similar among the hybrid types and white clover in every year, there was significant variation amongst families within the hybrid types in all years (depicted by the whiskers in Figure 2) $(\mathrm{P}<0.001)$.

The $\mathrm{BC}_{1}$ and $\mathrm{BC}_{2}$ hybrid types produced similar stolon densities and both were significantly greater than white clover (Table 3 ). $\mathrm{BC}_{1}$ hybrids had significantly smaller leaves than $\mathrm{BC}_{2}$, which were smaller than white clover. Both the hybrid and white clovers had low percentages of plants with green tissue (and therefore high levels of senescence) following the third summer, but there were no significant differences among the clovers (Table 3 ).

\section{Discussion}

In the rain shelter, the greater shoot dry weight of white clover compared with the hybrid generations in the Watered treatment was consistent with observations under standard field conditions at Lincoln (Nichols et al. 2014). However, when watering was withheld for almost 4 months, drought resistance in the $\mathrm{BC}_{1}$ hybrids was confirmed by significantly smaller effects on shoot biomass compared with $\mathrm{BC}_{2}$ hybrids and white clover. Changes in leaf area, internode length, petiole length, and senescence also support greater drought resistance in the $\mathrm{BC}_{1}$ generation. Correlations with the effect of water stress on shoot dry weight indicate that leaf area and senescence may be particularly important components of drought resistance. This includes inherent differences compared with white clover (e.g. smaller leaf size under control conditions) as well as drought induced changes that are likely be related to physiological traits or adaptations. For example, smaller changes in leaf size in $\mathrm{BC}_{1}$ hybrids may indicate a greater ability to maintain cell turgor under water stress (Nichols 2012).

Root traits were only a small component of this study, but data indicate that these may also play an important role in drought resistance of the hybrids. An increase in allocation of biomass to roots, as observed in the $\mathrm{BC}_{1}$ family, is a common response to drought stress (Chaves et al. 2003). A more vigorous root system may have enabled Kopu II BC $\mathrm{B}_{1}$ to keep stomata open and, therefore, maintain its photosynthetic rate, because it could replace the water lost through the stomata during this process. This may support the maintenance of important plant functions such as biomass accumulation and physiological components of drought resistance. Water stress did not damage the 
photosynthetic apparatus of the plants (Nichols 2012), therefore, the reduced photosynthetic rate by white clover and the $\mathrm{BC}_{2}$ hybrids simply reflect attempts by these clovers to limit water loss.

The field screening trial did not show any differences in summer growth between the hybrid types and white clover, which is consistent with the results in the Stressed treatment in the rain shelter. However, considerable variation for performance was evident among families within the hybrid types, particularly in the third summer when stress was most severe. These hybrids are very new in their development with little selection to date, particularly for drought resistance traits, so to identify this level of performance at an early stage suggests that selection among and within families may lead to population improvement above the level of elite white clover.

Apparent differences in drought resistance at Ashley Dene were presumably also due to adaptive traits in the hybrids such as small leaves and high stolon densities, which were evident in both the rain shelter and field experiments. Overall, the effects of soil moisture stress on many morphological and physiological traits appear to be significantly smaller for hybrids compared with white clover. These traits include smaller reductions in shoot DM, leaf area, and photosynthetic rate, smaller increases in shoot senescence, as well as moving resources below ground to develop a more vigorous root system. Hussain et al. (2012) also highlighted the presence of thicker, potentially more penetrating, roots in the hybrids as an important trait for water acquisition.

It is interesting to note that none of the hybrid or white clover types at Ashley Dene had intact tap roots by the third summer and reliance for moisture was on nodal roots, as in the rain shelter. White clover tap roots rarely last longer than 12-18 months after establishment, but Nichols (2012) did note a slight increase in tap root life span in unselected $\mathrm{BC}_{1}$ generation hybrids compared with white clover, under ambient rainfall at a nearby site. Lower leaf senescence in the hybrids, which was observed in the rain shelter, may not have eventuated in the screening trial as it is possible the roots of the spaced clover plants (in the absence of competition) were still able to extract sufficient water to maintain some growth. Screening trials with hybrid clovers may benefit from approaches that help induce stress, such as clover material grown within a grass based sward to maximise stress conditions.

These hybrids provide a novel pathway to improved germplasm, matching current trends in the pastoral sector. As well as pressures related to decreasing rainfall and an increasing frequency of drought, internal pressures within the pastoral industry are also becoming important. Competing land uses are increasingly limiting sheep/beef systems to drier, difficult to fertilise, hill areas. In 2013, almost $60 \%$ of the total national lamb flock was born and weaned on hill country (B+LNZ Economic service 2013). Development of better adapted germplasm for these land classes will be vital for the sheep/beef sector. Future evaluation of these interspecific hybrids, therefore, needs to include trials in dry hill country environments to verify their growth and persistence features.

The $T$. repens $\times T$. uniflorum hybrids offer a unique resource for providing persistent, perennial legumes under summer soil moisture deficits and dryland conditions in New Zealand. Their prostrate and stoloniferous nature suggests that they may also be able to cope well with competition from grass, and intensive grazing pressure. Our data indicate that as well as improvements to the mean, variation exists among hybrids for selection of improved material. Potentially, segregating populations with different combinations of traits may be developed for specific environments, including hill country, permanent dryland, and high rainfall/drought prone areas. Systems based screening will be part of more advanced evaluations.

\section{ACKNOWLEDGEMENTS}

Thanks to Plant and Food Research for use of the rain shelter, and Lincoln University for access to Ashley Dene. Advice from Rainer Hofmann, Dick Lucas, Chikako van Koten and Alasdair Noble; and technical assistance from Jackie Sammonds, Stephen Stilwell, Wouter Ballizany and Colin Pettigrew. Funding was provided by MBIE, DairyNZ and Grasslands Innovation Ltd.

\section{REFERENCES}

B+LNZ Economic Service 2013. Sheep and Beef Farm Survey 2013. Beef + Lamb New Zealand. http:// www.beeflambnz.com/

Chaves, M.M.; Maroco, J.P.; Pereira, J.S. 2003. Understanding plant responses to drought - from genes to the whole plant. Functional Plant Biology 30: 239-264.

Ellison, N.W.; Liston, A.; Steiner, J.J.; Williams, W.M.; Taylor, N.L. 2006. Molecular phylogenetics of the clover genus (Trifolium - Leguminosae). Molecular Phylogenetics and Evolution 39: 688-705.

Hussain, S.W.; Williams, W.M.; Verry, I.M.; Jahufer, M.Z.Z. 2012. A morphological and cytological analysis of interspecific hybrids: Trifolium repens $\mathrm{L}$. $\times$ T. uniflorum L. pp. 67-69. In: Australian Legume Symposium. Australian Grasslands Association, Melbourne.

Knowles, I.M.; Fraser, T.J.; Daly, M.J. 2003. White clover: loss in drought and subsequent recovery. Legumes for dryland pastures. Grassland Research and Practice Series 11: 37-42 
Nichols, S.N. 2012. Introgression of root and shoot characteristics in Trifolium repens $\times$ Trifolium uniflorum interspecific hybrids. $\mathrm{PhD}$. thesis. Lincoln University, New Zealand. http://hdl.handle. net/10182/5091

Nichols, S.N.; Hofmann, R.W.; Williams, W.M. 2014. The effect of interspecific hybridisation with Trifolium uniflorum on key white clover characteristics. Field Crops Research 161: 107-117.

Williams, W.M.; Verry, I.M.; Ansari, H.A.; Hussain, S.W.; Ullah, I.; Williamson, M.L.; Ellison, N.W. 2011. Eco-geographically divergent diploids, Caucasian clover (Trifolium ambiguum) and western clover (T. occidentale), retain most requirements for hybridization. Annals of Botany 108: 1269-1277.
Williams, W.M.; Verry, I.M.; Ansari, H.A.; Ellison, N.W.; Hussain, S.W.; Widdup, K.H.; Nichols, S.N.; Williamson, M.L.; Naeem, M.; Ullah, I. 2010. Splitting the white clover genome: radical new clovers for agriculture. Proceedings of the New Zealand Grassland Association 72: 273-276.

Widdup, K.H.; Hussain,S.W.; Williams,W.M.; Lowther, W.L.; Pryor, H.N. and Sutherland, B.L. 2003: The development and plant characteristics of interspecific hybrids between white and caucasian clover. Legumes for dryland pastures. Grassland Research and Practice Series 11: 143-148. 